\title{
IMPLEMENTASI KEBIJAKAN ZONASI PADA PENERIMAAN PESERTA DIDIK BARU JENJANG SMPN DI KOTA BANDUNG TAHUN 2018
}

Lia Melanie Ginting ${ }^{1 *}$, Asep Sumaryana ${ }^{2}$, Elisa Susanti ${ }^{3}$

${ }^{1}$ Kebijakan Publik, Universitas Padjadjaran, Jawa Barat Indonesia

${ }^{2}$ FISIP, Universitas Padjadjaran, Jawa Barat, Indonesia

${ }^{3}$ FISIP, Universitas Padjadjaran, Jawa Barat, Indonesia

*Korespondensi: liaginting12@gmail.com

\begin{abstract}
ABSTRAK
Kebijakan zonasi merupakan salah satu dari kebijakan pendidikan yang digunakan pada Penerimaan Peserta Didik Baru (PPDB) di setiap jenjang pendidikan formal dimulai dari SMPN sampai dengan SMAN/SMKN di Indonesia. PPDB adalah Penerimaan Peserta Didik Baru pada Taman Kanak-Kanak/Raudhatul Athfal, Sekolah Dasar/ Madrasah Ibtidaiyah, Sekolah Menengah Pertama/Madarasah Tsanawiyah yang dilaksanakan pada awal tahun ajaran baru.
\end{abstract}

Kata kunci: Kebijakan zonasi; implementasi; PPDB tahun 2018

\section{IMPLEMENTATION OF THE ZONING POLICY ON RECEIVING NEW MEMBERS OF THE COUNTRY'S FIRST-YEAR MIDDLE SCHOOL IN THE CITY OF BANDUNG IN 2018}

\begin{abstract}
Zoning policy is one of the educational policies used on accepting new proteges on each formal educational ladder ranging from the first high school of the country to high school or vocational high school. PPDB is the reception of new convert to Kindergarten/Raudhatul Athfal, Elementary School/ Madrasah Ibtidaiyah, Middle School/ Madrasah Tsanawiyah underway at the beginning of the new school year.
\end{abstract}

Key word: Zoning Policy, Implementation, PPDB in 2018

\section{PENDAHULUAN}

Pada tahun 2018, terjadi fenomena kebijakan zonasi di Kota Bandung, yakni setelah pengumuman hasil PPDB jenjang SMPN keluar ternyata banyak orang tua peserta didik dengan perasaan kecewa mendatangi Dinas Pendidikan Kota Bandung untuk mengadukan bahwa anak mereka selaku peserta didik yang akan melanjutkan pendidikannya ke SMPN yang dituju tidak diterima akibat dari kebijakan zonasi yang diimplementasikan pada PPDB jenjang SMPN. (Tabel 1.1) Mereka berdemonstrasi di depan Dinas Pendidikan Kota Bandung untuk di dengarkan aspirasi pengaduan mereka. Hal ini terjadi di tahun 2018 sedangkan pada tahun 2017 pelaksanaan PPDB jenjang SMPN di Kota Bandung berjalan dengan lancar padahal kebijakan zonasi ini telah dilakukan dari tahun 2017.
Perwal Kota Bandung No 456 Tahun 2018 Tentang Tata Cara Penerimaan Peserta Didik Baru Pada Taman Kanak-Kanak/ Raudhatul Athfal, Sekolah Dasar/ Madrasah Ibtidaiyah Dan Sekolah Menengah Pertama/ Madrasah Tsanawiyah Tahun 2018 mengatur berapa persen kuota zonasi yang harus sekolah terima yaitu paling sedikit lima puluh persen (50\%). Hal ini menjadi masalah ketika kuota zonasi ditetapkan paling sedikit lima puluh persen (50\%) tapi tidak diimbangi dengan kapasitas daya tampung SMPN di Kota Bandung. Hal ini dikarenakan perbandingan antara jumlah SDN dengan SMPN yang tidak seimbang mempengaruhi daya tampung siswa yang diterima di SMPN. (tabel 1.1) Penelitian ini bertujuan untuk mengetahui mengapa implementasi kebijakan zonasi pada PPDB jenjang SMPN di Kota Bandung belum berjalan dengan baik? 
Tabel 1.1

Data Statistik PPDB SMP Zonasi

\begin{tabular}{|c|c|c|c|}
\hline Nama & (Dalam Ribuan) & $(\%)$ & Keterangan \\
\hline Jumlah Lulusan SD & $39.678,00$ & 100 & \\
\hline Jumlah Pendaftar & $18.831,00$ & $47,46 \%$ & Dari Jumlah Lulusan \\
\hline $\begin{array}{lll}\text { Selisih Antara } & \text { Pendaftar dan } \\
\text { Jumlah Lulusan } & & \\
\end{array}$ & $20.847,00$ & $52,54 \%$ & \\
\hline Jumlah Diterima Ke SMPN & $11.362,00$ & $60,34 \%$ & Dari Jumlah Pendaftar \\
\hline Jumlah Yang Tidak Diterima & $7.469,00$ & $39,66 \%$ & Dari Jumlah Pendaftar \\
\hline Pendaftar Memilih Swasta & - & - & \\
\hline $\begin{array}{l}\text { Pendaftar Memilih Negeri (SMP \& } \\
\text { MTS) }\end{array}$ & $18.831,00$ & $100,00 \%$ & Dari Jumlah Pendaftar \\
\hline $\begin{array}{l}\text { Pendaftar Memilih Negeri (SMP } \\
\text { Saja) }\end{array}$ & $18.443,00$ & $97,94 \%$ & \\
\hline $\begin{array}{l}\text { Pendaftar Memilih Negeri (MTS } \\
\text { Saja) }\end{array}$ & 388,00 & $2,06 \%$ & \\
\hline $\begin{array}{l}\text { Jumlah Pendaftar Yg Nilai UN } \\
\text { Diatas Rata-rata }\end{array}$ & $13.611,00$ & $72,28 \%$ & Dari Jumlah Pendaftar \\
\hline $\begin{array}{l}\text { Jumlah Pendaftar Yang Nilai UN } \\
\text { Dibawah Rata-rata }\end{array}$ & $5.220,00$ & $27,72 \%$ & Dari Jumlah Pendaftar \\
\hline $\begin{array}{l}\text { Jumlah Pendaftar Yang Diterima } \\
\text { Dengan Nilai UN Diatas Rata-rata }\end{array}$ & $7.825,00$ & $68,87 \%$ & Dari Yang Diterima \\
\hline $\begin{array}{l}\text { Jumlah Pendaftar Yang Diterima } \\
\text { Dengan Nilai UN Dibawah Rata- } \\
\text { rata }\end{array}$ & $3.537,00$ & $31,13 \%$ & Dari Yang Diterima \\
\hline $\begin{array}{l}\text { Jumlah Pendaftar Tidak Diterima } \\
\text { Dengan Nilai UN Diatas Rata-Rata }\end{array}$ & $5.786,00$ & $77,47 \%$ & Dari Yang Tidak Diterima \\
\hline $\begin{array}{l}\text { Jumlah Pendaftar Tidak Diterima } \\
\text { Dengan Nilai UN Dibawah Rata- } \\
\text { Rata }\end{array}$ & $1.683,00$ & $22,53 \%$ & Dari Yang Tidak Diterima \\
\hline
\end{tabular}

Sumber: Dinas Pendidikan Kota Bandung

Berdasarkan data dari Dinas Pendidikan Kota Bandung bahwa jumlah lulusan SD (Negeri dan Swasta) di Kota Bandung sebanyak 39.678,00 orang dan jumlah peserta yang mendaftar sebanyak 18.831,00 (47. 46\%) calon peserta

\section{TINJAUAN PUSTAKA}

Implementasi kebijakan mengandung pengertian sebuah upaya atau proses untuk menjalankan atau melaksanakan sebuah keputusan kebijaksanaan, biasanya dalam bentuk Undang-Undang, Peraturan Pemerintah. (Wahab, 1997:64) Menurut Lester dan Stewart Jr (2000:14) implementasi merupakan sebagai suatu proses dan suatu hasil. Keberhasilan dari sebuah implementasi dapat dilihat dari bagaimana implementasi itu dijalankan dan apakah didik, yang diterima sebanyak 11.362,00 (60, 34\%) calon peserta didik kelas 7 (SMP) dari jumlah pendaftar dan yang tidak diterima sebanyak 7.469,00 (39.66 \%) calon peserta didik.

proses implementasi ini mampu mencapai tujuan yang telah ditentukan sebelumnya. Implementasi pada sisi yang lain merupakan fenomena yang kompleks yang mungkin dapat dipahami sebagai suatu proses, suatu keluaran (output) maupun sebagai suatu dampak (outcome). Sekalipun implementasi merupakan fenomena yang kompleks, konsep ini dipahami sebagai suatu proses, suatu keluaran dan suatu dampak. 
Deskripsi tentang konsep implementasi dikemukakan oleh Lane (2000), yang mengemukakan bahwa:

"The concept of implementation is characterized by a problematic structure. Webster's Dictionary states that 'implementation' means either the act of implementing or the state of having been implemented; it presents the following key words for 'implement': to carry out: accomplish, fulfil; to give practical effect to and ensure of actual fulfihnent by concrete measures, to provide instruments or means of practical expression.

'To carry out something' or 'to accomplish something' may sound intelligible and require little explication. A formal definition might be:

(DF1) Implementation $=F($ Intention, Output, Outcome)

Deskripsi sederhana tentang teori konsep implementasi yang dikemukakan oleh Lane (2000) bahwa implementasi sebagai konsep dapat dibagi ke dalam dua bagian yakni implementasi merupakan persamaan fungsi dari maksud, output dan outcome. Berdasarkan deskripsi tersebut, formula implementasi merupakan fungsi dari maksud dan tujuan, hasil sebagai produk dan hasil dari akibat. Selanjutnya, Lane (2000) mengemukakan bahwa:

"By developing the original implementation formula we are now at a stage where a more powerful and complex concept of implementation may be introduced: (DF2)

Implementation $=F$ (Policy, Outcome, Formator, Implementor, Initiator, Time)"

Definisi formal implementasi yakni implementasi merupakan persamaan fungsi dari Intention, output dan outcome. Dengan mengembangkan formulasi implementasi yang asli kita sekarang berada di tahap dimana suatu konsep implementasi yang lebih kuat dan kompleks dapat diperkenalkan bahwa implementasi merupakan persamaan fungsi dari Policy (Kebijakan), Formator, Implementor, Initiator (inisiator/pemrakarsa), Time (waktu). Penekanan utama kedua fungsi ini adalah kepada kebijakan itu sendiri, kemudian hasil yang dicapai dan dilaksanakan oleh implementor dalam kurun waktu tertentu. (Sabatier, 1986: 21-48) Kemudian, Lane (2000) juga mengemukakan bahwa:

"Implicit in implementation theory is the idea that the actors who decide on policy are different from the actors who are responsible for the implementation of policy. Though this is far from always the case, the implementation process is built up around an asymmetric relationship between the forma tors of policy and the implementors of policy. The formators may not be the initiators of policy; be that as it may, the theory of implementation assumes that public policy becomes a legitimate concern for implementors once it has been decided upon in formally defined ways."

Penjelasan di atas menunjukkan bahwa secara tersirat, teori implementasi adalah gagasan bahwa aktor yang menentukan kebijakan berbeda dari aktor yang bertanggung jawab dalam menerapkan kebijakan. Meskipun ini jauh dari yang selalu terjadi, proses implementasi di bangun di sekitar hubungan asimetris antara para pembuat kebijakan dan para penyelenggara kebijakan. Para pembuat kebijakan mungkin bukan pemrakarsa kebijakan; jadilah bahwa seperti itu, teori diterapkan dengan asumsi bahwa kebijakan publik menjadi kepedulian yang sah bagi para penyelenggara kebijakan setelah itu diputuskan secara resmi.

Implementasi kebijakan yang melibatkan banyak organisasi atau berbagai tingkatan struktur birokrasi dapat dilihat dari 3 (tiga) sudut pandang, sebagaimana dikemukakan Wahab (2005:63) yakni 1) Pemrakarsa kebijakan atau the center, 2) Pejabat Pelaksana 
di lapangan atau the periphery, 3) Aktor perorangan di luar badan pemerintah kepada siapa program itu ditujukan yakni kelompok sasaran atau target grup.

Dari sudut pandang the center, fokus implementasi kebijakan akan mencakup usaha yang dilakukan pejabat atasan atau lembaga tingkat pusat untuk mendapatkan kepatuhan dari lembaga atau pejabat di tingkat daerah. Bila program ternyata tidak berjalan sebagaimana mestinya maka kemungkinan akan dilakukan upaya penyeseuaian terhadap program atau pengenaan sanksi hukuman kepada pejabat yang bertanggung jawab atau kebijakan itu dirumuskan kembali. Meskipun demikian, perhatian utama dari pusat ini biasanya berkenaan dengan masalah, pertama, sejauhmanakah tujuan atau sasaran resmi kebijakan telah dicapai, kedua, apakah alasan yang menyebabkan tujuan atau sasaran tertentu tercapai atau tidak.

Kemudian, dari perspektif the periphery atau pejabat lapangan, implementasi kebijakan akan terfokus pada tindakan atau perilaku para pejabat dan instansi di lapangan yang dalam upaya untuk menanggulangi gangguan yang terjadi di wilayah kerjanya yang disebabkan oleh usaha-usaha dari pejabat lain di luar instansinya demi berhasilnya kebijakan dimaksud. Selanjutnya implementasi kebijakan dari perspektif target masyarakat lebih terkait dengan jaminan bagi kelompok sasaran dan masyarakat seluruhnya untuk dapat menerima dan menikmati hasil atau keuntungan dari kebijakan atau beneficiaries, maka pandangan mereka mungkin saja serupa dengan pandangan dan persepsi para pejabat pusat yakni sejauhmanakah pelayanan yang direncanakan melalui kebijakan itu benarbenar telah diberikan. Sekalipun demikian, kelompok sasaran itu kemungkinan akan lebih memusatkan perhatian pada permasalahan apakah pelayanan yang telah diberikan tersebut benar-benar mengubah pola hidupnya, benar-benar memberikan dampak positif dalam jangka panjang bagi peningkatan mutu hidup termasuk pengetahuan mereka. Pemahaman yang mendalam akan persepsi masyarakat sangat penting artinya.

Pemahaman konsep implementasi kebijakan dari perspektif pusat, daerah dan masyarakat di atas akan mampu menjamin tercapainya tujuan kebijakan secara optimal dan memuaskan berbagai pihak stakeholders yang terkait langsung dan tidak langsung dengan tujuan dan sasaran implementasi kebijakan itu. Dengan demikian, proses implementasi kebijakan sesungguhnya tidak hanya menyangkut perilaku badan-badan administratif yang bertanggung jawab untuk melaksanakan program dan menimbulkan ketaatan pada diri kelompok sasaran tetapi juga menyangkut jaringan kekuatan politik, ekonomi dan sosial yang langsung atau tidak langsung dapat mempengaruhi perilaku dari semua pihak yang terlibat dan yang akhirnya berpengaruh terhadap dampak yang diharapkan maupun yang tidak diharapkan.

Berdasarkan dari berbagai definisi implementasi kebijakan tersebut maka dalam penelitian ini dapat disimpulkan bahwa implementasi kebijakan zonasi merupakan penetapan dari kebijakan publik supaya dapat dilaksanakan dengan baik sebagaimana yang telah direncanakan sebelumnya dan mempunyai dampak atau tujuan yang diinginkan.

Kemudian, untuk proses implementasi teori Mazmanian dan Sabatier (Rusli, 2015:108109) menyatakan bahwa peran penting dari implementasi kebijakan publik adalah kemampuannya dalam mengidentifikasikan variabel-variabel yang mempengaruhi tercapainya tujuan-tujuan formal pada keseluruhan tahapan proses implementasi. Selanjutnya, variabel-variabel tersebut secara umum dapat diklasifikasikan menjadi tiga (3) kategori variabel bebas, yaitu:

1) Tractability of the problem (Risalah tentang tingkat kesulitan permasalahan yang akan dikendalikan/ Mudah atau tidaknya masalah dikendalikan), dengan indikator: 
a. Kesukaran-kesukaran teknis/ ketersediaan teori teknis dan teknologi yang valid;

b. Keragaman perilaku kelompok sasaran.

c. Prosentase kelompok sasaran dalam totalitas penduduk;

d. Tingkat dan ruang lingkup perubahan perilaku yang dikehendaki/ Ruang lingkup atau derajat perubahan perilaku yang diinginkan;

2) Ability of policy decision to structure implementation (kemampuan keputusan kebijakan dalam menstrukturkan proses implementasi), dengan indikator:

a. Kejelasan dan konsistensi tujuan;

b. Digunakannya teori kausal yang handal;

c. Ketepatan alokasi sumber dana;

d. Keterpaduan hierarki di dalam lingkungan dan di antara lembagalembaga/ Instansi-instansi pelaksana;

e. Aturan-aturan pembuatan keputusan dari institusi pelaksana;

f. Komitmen dan rekruitmen para pejabat pelaksana;

g. Akses formal pihak luar;

3) Non-statutory variables affecting implementation (variabel-variabel di luar kebijakan/peraturan perundangan yang mempengaruhi implementasi), ditentukan oleh indikator:

a. Kondisi sosio-ekonomi dan teknologi;

b. Dukungan publik;

c. Sikap dan sumber-sumber yang dimiliki kelompok-kelompok masyarakat;

d. Dukungan dari pejabat/institusi atasan yang berwenang;

e. Komitmen dan kepemimpinan para pejabat pelaksana/ Kesepakatan dan Kemampuan Kepemimpinan Para Pejabat Pelaksana.

Menurut Ndraha (2003, 64-65) pelayanan dalam administrasi adalah pelayanan yang mencakup dalam arti kegiatan apapun isinya. Administrasi terdapat dalam bentuk atau corak negara apa saja, baik totaliter, otoriter maupun demokratik. Sementara itu dalam Kybernologi, kebutuhan istimewa manusia disebut jasa publik dan layanan civil, keduanya dapat disebut layanan. Layanan adalah proses, output, produk, hasil dan manfaat. Proses produksi, distribusi, dan seterusnya sampai konsumer mendapat manfaat (outcome) yang diharapkannya, disebut pelayanan. Jadi, pelayanan dalam Kybernologi adalah pelayanan publik dan pelayanan sipil dalam arti proses, produk, dan outcome yang bersifat istimewa yang dibutuhkan oleh manusia dan diproses sesuai dengan aspirasi manusia pula. Undang-Undang No. 25 Tahun 2009 tentang Pelayanan Publik mengatakan bahwa:

"Pelayanan publik merupakan kegiatan atau rangkaian kegiatan dalam rangka pemenuhan kebutuhan pelayanan sesuai dengan peraturan perundangundangan bagi setiap warga negara dan penduduk atas barang, jasa atau pelayanan administratif yang disediakan oleh penyelenggara pelayanan publik.”

Menurut Undang-undang ini pelayanan dapat dibedakan ke dalam dua bentuk yaitu: Pelayanan administratif dan Pelayanan barang. Penyelenggara pelayanan publik sektor pemerintah diselenggarakan oleh unsur seperti: penyelenggara negara, penyelenggara ekonomi Negara, Koperasi dan lembagalembaga pelayanan yang ditunjuk oleh Negara. Proses PPDB jenjang SMPN di Kota Bandung tahun 2018 merupakan pelayanan publik yang diberikan oleh penyelenggara pelayanan public sector pemerintah dalam rangka memberikan layanan pendidikan kepada masyarakat di Kota Bandung.

Mazmanian dan Sabatier (1983:4) menjelaskan makna implementasi dengan mengatakan bahwa "memahami apa yang senyatanya terjadi sesudah suatu program dinyatakan berlaku atau dirumuskan yang mencakup baik usaha-usaha untuk mengadministrasikannya maupun untuk menimbulkan dampak nyata pada masyarakat atau kejadian-kejadian”. Definisi ini menekankan tidak hanya melibatkan perilaku badan-badan administratif yang bertanggungjawab untuk melaksanakan program dan menimbulkan ketaatan pada diri kelompok sasaran, tetapi juga menyangkut jaringan kekuatan politik, ekonomi dan sosial 
yang langsung tidak langsung dapat mempengaruhi perilaku dari semua pihak terlibat, dan pada akhirnya berpengaruh terhadap dampak-baik yang diharapkan (intended) maupun yang tidak diharapkan (unintended) dari suatu program.

Lazimnya keputusan tersebut mengidentifikasi masalah yang ingin diatasi, menyebutkan secara tegas tujuan/sasaran yang ingin dicapai, dan berbagai macam cara untuk menstrukturkan/mengatur proses implementasinya. Proses ini berlangsung setelah melalui sejumlah tahapan tertentu, biasanya diawali dengan tahapan pengesahan undang-undang, kemudian output kebijakan dalam bentuk pelaksanaan keputusan oleh badan (instansi) pelaksana, kesediaan dilaksanakannya keputusan-keputusan tersebut oleh kelompok-kelompok sasaran, dampak nyata baik yang dikehendaki atau yang tidak dari output tersebut, dampak keputusan dipersepsikan oleh badan-badan yang mengambil keputusan, dan akhirnya perbaikan-perbaikan penting atau upaya untuk melakukan perbaikan- perbaikan terhadap undang-undang/ peraturan-peraturan yang bersangkutan.

Menurut Hogwood dan Gunn (1984) kebijakan yang gagal dapat dibagi dalam dua kemungkinan yaitu non-implementation (tidak terimplementasikan) dan unsuccessful implementation (implementasi yang tidak berhasil). Tidak terimplementasikan (nonimplementation) maksudnya adalah suatu kebijakan tidak dilaksanakan sesuai dengan ketentuan-ketentuan yang seharusnya, baik itu karena adanya pihak-pihak yang tidak mau bekerjasama, inefisiensi dalam implementasi, tidak ada kontrol dalam pelaksanaan. Ketidakmampuan implementor dalam menguasai permasalahan sehingga walaupun telah dilaksanakan secara sungguh-sungguh tetap tidak mencapai efektifitas implementasi kebijakan. Implementasi yang tidak berhasil (unsuccessful implementation) merupakan suatu kegagalan dalam implementasi apabila kebijakan tersebut telah dilaksanakan sesuai ketentuan namun dalam kenyataannya ada faktor-faktor lain yang mempengaruhi kebijakan tersebut sehingga kebijakan tidak dapat dilaksanakan. Suatu kebijakan dapat dilihat sebagai mungkin memiliki resiko yang gagal apabila disebabkan oleh pembuat kebijakan merasa bahwa pelaksanaan kebijakan memang buruk (bad execution), atau pembuat kebijakan dan pelaksana kebijakan bersepakat bahwa ternyata kebijakan tersebut tidak bisa dilaksanakan karena faktor ekstrnal yang jelek bagi efektiivitas implementasi sehingga diasumsikan kebijakan tersebut mengalami nasib buruk (bad luck). Terakhir, adalah kemungkinan suatu kebijakan dinyatakan gagal apabila kebijakan tersebut ternyata memang telah dirumuskan secara tidak tepat, informasi pada perumusan kebijakan tidak memadai, asumsi-asumsi yang tidak tepat, atau memiliki pengharapan yang lebih pada hasil implementasi sehingga kebijakan tersebut tidak realistis untuk diimplementasikan (bad policy).

\section{METODE PENELITIAN}

Penelitian ini menggunakan metode penelitian deskriptif kualitatif. Sumber data penelitian ini terdiri dari: 1) data primer; 2) data sekunder. Teknik pengumpulan data pada penelitian ini dengan cara: 1) pengumpulan data melalui teknik wawancara; 2) Pengumpulan data melalui studi literatur; 3) pengumpulan data melalui observasi; 4) dokumentasi. Untuk teknik analisa data dilakukan mengacu pendapat Nasution (1996:129), yaitu: Reduksi Data. Reduksi data dilakukan dengan cara membuat rangkuman terhadap aspekaspek permasalahan yang diteliti dalam melakukan langkah-langkah analisis berikutnya; Penyajian data, penyajian data secara jelas dan singkat akan memudahkan dalam memahami gambaran terhadap aspek-aspek yang diteliti secara keseluruhan maupun bagian demi bagian; Pengambilan dan verifikasi, langkah terakhir dari kegiatan analisis data yang dilakukan dalam penelitian ini yaitu pengambilan kesimpulan dan verifikasi. Kesimpulan dalam tahap ini berarti memaknai terhadap data yang telah terkumpul dan 
kesimpulan dibuat dalam bentuk pernyataan singkat dan mudah dipahami mengacu pada permasalahan yang diteliti. Untuk menentukan keabsahan data, Penulis menggunakan teknik triangulasi yakni teknik pemeriksaan keabsahan data dengan cara memanfaatkan sesuatu yang lain di luar data itu sendiri untuk keperluan pengecekan atau sebagai pembanding terhadap data itu.

\section{HASIL DAN PEMBAHASAN}

\section{Isi Hasil dan Pembahasan}

1. Intention (Maksud). Menurut informan keI maksud dibuatnya kebijakan zonasi ialah supaya pendidikan kembali kepada fungsi yang sebenarnya, sedangkan informan ke2 mengatakan untuk mendekatkan peserta didik antara rumah tinggal dengan sekolah dan supaya anak lebih fresh ketika mengikuti kegiatan belajar mengajar (KBM) juga tidak capek, sedangkan informan ke-3 mengatakan pemerintah ingin membuat anak-anak di Kota Bandung ke sekolah dengan kondisi yang lebih bugar kemudian karena sekolah dekat efeknya mengurangi kemacetan juga mengurangi biaya transportasi yang dikeluarkan oleh orang tua karena peserta didik ke sekolah dengan berjalan kaki dan bersepeda ini adalah upaya pemerataan pendidikan. Berdasarkan Teori Lane (2000) bahwa implementasi merupakan persamaan fungsi dari maksud, hasil sebagai produk dan hasil dari akibat. Berdasarkan hasil observasi yang Penulis dapatkan kemudian dipersepsikan oleh Penulis, kebijakan zonasi yang diimplementasikan pada PPDB jenjang SMPN di Kota Bandung tahun 2018 memiliki maksud untuk pemerataan dan keadilan dalam mengakses pendidikan di Kota Bandung meningkat, untuk mengurangi kemacetan, untuk tidak ada lagi sekolah favorit dan tidak favorit dan untuk meningkatkan kualitas pendidikan di Kota Bandung. Hal ini sesuai dengan teori Lane (2000) suatu kebijakan harus memiliki maksud dibuatnya suatu kebijakan publik.

2. Policy (Kebijakan). Policy atau kebijakan zonasi tertuang dalam dokumen resmi yakni Perwal Kota Bandung nomor 456 Tahun 2018. Berdasarkan teori Lane (2000) mengemukakan bahwa implementasi kebijakan sebagai konsep dapat di bagi ke dalam dua bagian yakni implementasi merupakan persamaan fungsi yang pertama dari maksud (intention), hasil sebagai produk (Output) dan hasil dari akibat (Outcome) dan persamaan fungsi kedua dari Policy (Kebijakan), Formator, Implementor, Initiator, Time (Waktu). Penekanan utama kedua fungsi ini adalah kebijakan itu sendiri. Berdasarkan hasil observasi maka Penulis berasumsi bahwa policy atau kebijakan zonasi dikeluarkan oleh pemerintahan maka kebijakan zonasi pada PPDB jenjang SMPN di Kota Bandung tahun 2018 tertuang dalam dokumen resmi seperti dalam bentuk Perwal Kota Bandung nomor 456 Tahun 2018.

3. Formator, menurut informan ke-I yakni adanya unsur pemerintah (Dinas Pendidikan), unsur sekolah, LSM peduli pendidikan, perangkat pemerintah daerah yang terkait misalnya Dinas Kependudukan dan Catatan Sipil yang mengeluarkan akta kelahiran lalu ada bagian hukum untuk melakukan harmonisasi hukum. Berdasarkan teori Lane (2000) formator merupakan aktor yang membuat kebijakan dan para pembuat kebijakan mungkin bukan pemrakarsa. Berdasarkan hasil observasi maka penulis mengasumsikan bahwa formator kebijakan zonasi pada PPDB jenjang SMPN di Kota Bandung tahun 2018 Menteri Pendidikan Dan Kebudayaan (Kemdikbud).

4. Implementor, kebijakan zonasi menurut informan ke-I adalah sekolah dan Dinas Pendidikan tetapi ada juga keterlibatan dari unsur daerah kelurahan misalnya SKTM yang menentukan sekolah, Lurah, RT, RW menjadi implementor juga karena harus menetapkan siapa yang miskin dan bukan miskin sedangkan menurut informan ke-2 Dinas Pendidikan, kepala sekolah dan panitia PPDB. Berdasarkan teori Lane (2000) implementor adalah para penyelenggara kebijakan. Berdasarkan hasil observasi maka penulis mempersepsikan bahwa implementor kebijakan zonasi pada PPDB jenjang SMPN di Kota Bandung tahun 2018 adalah jajaran Pemerintah Kota Bandung yang terkait dengan Pendidikan. 
5. Initiator/Inisiator (Pemrakarsa) kebijakan zonasi menurut informan ke-I adalah: "Nah, sebenarnya kalau di Tahun 2018 ini Kita sudah perintah dari Menteri ya cuman kalau di Bandung ini 2018 sebetulnya penyempurnaan saja dari perjalanan yang sudah diinisiasi oleh Bapak Walikota dan Kita Dinas Pendidikan dan dalam beberapa perbaikannya sehingga 2018 itu walaupun kuotanya sudah ditetapkan oleh Menteri sebesar Sembilan puluh persen zonasi Kita tetap melakukan modifikasi jadi dalam hal ini Walikota dan Dinas Pendidikan inisiator untuk menetapkan.”

Berdasarkan teori Lane (2000) mengemukakan bahwa initiator adalah pemrakarsa suatu kebijakan (inisiator). Berdasarkan hasil observasi maka Penulis mempersepsikan bahwa inisiator atau pemrakarsa kebijakan zonasi pada PPDB jenjang SMPN adalah Presiden RI, Bapak Joko Widodo berdasarkan UU Nomor 23 Tahun 2003 tentang Sistem Pendidikan Nasional dan amanat Nawa cita Presiden untuk mengurangi kesenjangan yang terjadi di masyarakat maka melalui Kementerian Pendidikan dan Kebudayaan melakukan upaya menghadirkan pemerataan akses pada layanan pendidikan serta pemeratan kualitas pendidikan nasional dalam bentuk kebijakan zonasi.

6. Time (Waktu). Berdasarkan Perwal Kota Bandung Nomor 456 Tahun 2018, Pasal 10 , menyatakan bahwa penetapan tanggal dan waktu pendaftaran peserta didik baru ditetapkan oleh Kepala Dinas dengan berpedoman pada kalender akademik. Apabila kita lihat kalender akademik maka tanggal pendaftaran peserta didik baru untuk tahun ajaran 2018/2019 yaitu pada tanggal 2-7 Juli 2018 dan untuk pengumuman PPDB tahun ajaran 2018/2019 tingkat Kota Bandung pada tanggal 9 Juli 2018, hari senin. Teori Lane (2000) mengemukakan bahwa dalam kurun waktu tertentu implementor mencapai hasil dengan dilaksanakannya suatu kebijakan publik. Berdasarkan hasil observasi dan kemudian Penulis mempersepsikan bahwa implementasi kebijakan zonasi pada PPDB jenjang SMPN di Kota Bandung tahun 2018 telah sesuai dengan teori Lane, bahwa implementor pada tanggal 9 Juli 2018 telah mendapatkan hasil yang ingin dicapai dengan dilaksanakannya implementasi kebijakan zonasi pada PPDB jenjang SMPN di Kota Bandung tahun 2018. Hasil yang ingin dicapainya adalah dengan mengumumkan nama-nama calon peserta didik di jenjang SMPN yang diterima melalui PPDB online.

7. Proses Implementasi. Untuk menjelaskan proses implementasi kebijakan zonasi pada PPDB jenjang SMPN di Kota Bandung Tahun 2018, Penulis menggunakan teori dari Mazmanian dan Sabatier sebagai berikut:

1) Tractability Of The Problem (Mudah atau tidaknya masalah dikendalikan), Di dalam merekrut peserta didik baru, Dinas Pendidikan Kota Bandung memakai teknologi dan teori teknis di dalam merekrut peserta didik baru begitu juga di dalam menetapkan jarak antara sekolah dengan domisili peserta didik dengan menggunakan teknologi, yaitu google map. Keragaman perilaku kelompok sasaran juga ada di kebijakan zonasi yang diimplementasikan pada PPDB jenjang SMPN di Kota Bandung tahun 2018, sehingga semakin sulit untuk membuat peraturan yang tegas dan jelas. Hal ini terjadi pada Perwal Kota Bandung no 456 Tahun 2018 yang mengalami diskresi dengan dikeluarkannya Surat Keputusan Kepala Dinas nomor 420/2513Disdik tentang Petunjuk Teknis (Juknis) PPDB.

Prosentase kelompok sasaran pada kebijakan zonasi yang diimplementasikan pada PPDB jenjang SMPN di Kota Bandung tahun 2018 sebesar jumlah lulusan SD yakni 39.678 orang (Tabel 1.1). 
Prosentase kelompok sasaran yang sebesar 39.678 orang merupakan prosentase yang kecil dibandingkan totalitas penduduk Kota Bandung sebesar 2.5 juta jiwa pada tahun 2018. Teori Mazmanian dan Sabatier mengemukakan bahwa semakin kecil dan semakin jelas kelompok sasaran yang akan diubah maka semakin besar jumlah perubahan perilaku yang dikehendaki. Kelompok sasaran implementasi kebijakan zonasi pada PPDB jenjang SMPN di Kota Bandung tahun 2018 kecil dan jelas yang akan diubah maka jumlah perubahan perilaku yang diinginkan oleh kebijakan zonasi dari kelompok sasaran semakin besar. Begitu juga dengan derajat perubahan perilaku yang diinginkan oleh kebijakan zonasi dari kelompok sasaran. Derajat Perubahan yang diinginkan salah satunya adalah adanya perubahan mindset kelompok sasaran di dalam masukkan anaknya ke SMP, dulu kelompok sasaran mindsetmya selalu ingin memasukkan anaknya ke SMPN terutama SMPN Favorit tapi dengan adanya kebijakan zonasi diharapkan adanya derajat perubahan yaitu memasukkan anaknya ke SMPN yang dekat dengan domisili/ rumah walaupun SMPN tersebut bukan SMPN favorit.

2) Ability Of Policy Decision To Structure Implementation (Kemampuan Keputusan Kebijakan Dalam Mens trukturkan Proses Implementasi). Kebijakan zonasi yang diimplementasikan pada PPDB jenjang SMPN di Kota Bandung tahun 2018 memiliki kejelasan dan konsisten tujuan. Berdasarkan hasil observasi di lapangan maka penulis mempersepsikan bahwa tujuan kebijakan zonasi yang diimplementasikan pada PPDB jenjang SMPN di Kota Bandung, yakni: 1. Supaya tidak/mengurangi kemacetan; 2. Tidak lagi sekolah favorit dan bukan favorit; 3. Untuk meratakan pendidikan di Kota Bandung. Kebijakan zonasi yang diimplementasikan pada PPDB jenjang SMPN di Kota Bandung tahun 2018 menggunakan teori kausal yang handal tertuang di dalam Perwal Kota Bandung no 456 tahun 2018, pasal 21 mengatakan bahwa Dinas sesuai dengan kewenangannya mengkoordinasikan dan memantau pelaksanaan PPDB. Berdasarkan hasi observasi maka persepsi Penulis bahwa implementasi kebijakan zonasi menggunakan teori kausal yang handal yakni teori koordinasi antara badan-badan penyelenggara kebijakan zonasi. Pengalokasian sumber dana implementasi kebijakan zonasi pada PPDB jenjang SMPN di Kota Bandung tahun 2018 sudah tepat yang dimana pihak sekolah menggunakan Dana BOS (Bantuan Operasional Sekolah) yang bersumber dari APBN sedangkan Dinas Pendidikan Kota Bandung di dalam menyelenggarakan implementasi kebijakan zonasi pada PPDB jenjang SMPN di Kota Bandung tahun 2018 menggunakan APBD.

Perwal Kota Bandung no 456 tahun 2018, di bagian mengingat, nomor 6 mengatakan bahwa Peraturan Menteri Pendidikan Dan Kebudayaan Nomor 17 tahun 2017 tentang Penerimaan Peserta Didik Baru Pada Taman Kanak-Kanak, Sekolah Dasar, Sekolah Menengah Pertama, Sekolah Menengah Atas, Sekolah Menengah Kejuruan atau bentuk lainnya yang sederajat merupakan peraturan perundangan yang baik karena memiliki kemampuan untuk memadukan hierarki badan-badan pelaksana implementasi kebijakan zonasi pada PPDB jenjang SMPN di Kota Bandung tahun 2018. Di dalam Perwal Kota Bandung no 456 tahun 2018 mengatur tentang aturan-aturan pembuatan keputusan dari institusi pelaksanaan, pada Pasal 4 ayat (1) butir a, menyatakan bahwa sekolah yang diselenggarakan oleh Pemerintah Daerah Kota wajib menerima calon peserta didik dengan kuota zonasi paling sedikit 50\% (lima puluh) persen dan berdasarkan para informan mengatakan bahwa kuota 
zonasi yang ditentukan paling sedikit $50 \%$ dilakukan berdasarkan data pemetaan yang di dapatkan dari kajian-kajian yang dilakukan oleh Dinas Pendidikan Kota Bandung melalui FGD-FGD (forum grup diskusi) dilihat per wilayahnya karena sekolah yang diselenggarakan oleh Pemerintah Daerah Kota Bandung belum merata antara sekolah dasar negeri (SDN) dengan sekolah menengah pertama negeri (SMPN). Para pejabat pelaksana implementasi kebijakan zonasi pada PPDB jenjang SMPN di Kota Bandung tahun 2018 berkomitmen untuk mensukseskan kebijakan zonasi dan untuk rekruitmen dilakukan sesuai dengan job desk/ tugas pokok dan fungsi para pejabat pelaksana. Akses formal pihak luar merupakan faktor yang dapat mempengaruhi implementasi kebijakan zonasi pada PPDB jenjang SMPN di Kota Bandung tahun 2018. Kelompok sasaran tidak puas dengan kebijakan zonasi ini berpeluang untuk berpartisipasi mempengaruhi para pendukung kebijakan zonasi yang diimplementasikan pada PPDB jenjang SMPN di Kota Bandung tahun 2018.

3) Non-statutory variables affecting implementation (variabel-variabel di luar kebijakan/peraturan perundangan yang mempengaruhi implementasi). Kondisi sosio-ekonomi tidak berpengaruh terhadap upaya pencapaian tujuan berdasarkan undang-undang namun faktor teknologi berpengaruh terhadap upaya pencapaian tujuan implementasi kebijakan zonasi pada PPDB jenjang SMPN di Kota Bandung tahun 2018. Implementasi kebijakan zonasi pada PPDB jenjang SMPN di Kota Bandung tahun 2018 di dukung oleh kelompok sasaran maupun bukan kelompok sasaran,menurut salah seorang informan. Teori Mazmanian dan
Sabatier mengemukakan dukungan publik bagi tujuan undang-undang merupakan variabel yang dapat mempengaruhi implementasi kebijakan zonasi. Perubahan tertentu dalam sikap dan sumber-sumber yang dimiliki adalah perubahan cara pandang/cara berpikir/ mindset yang dimiliki kelompok masyarakat dapat mempengaruhi implementasi kebijakan zonasi. Implementasi kebijakan zonasi pada PPDB jenjang SMPN di Kota Bandung tahun 2018 memperoleh dukungan dari pejabat/institusi atasan yang berwenang. Komitmen dan kepemimpinan para pejabat pelaksana kebijakan zonasi mempengaruhi langsung terhadap output kebijakan badan-bdan pelaksana.

8. Output. Berdasarkan data statistic PPDB SMPN zonasi (tabel 1.1) peserta didik masih banyak yang tidak diterima ke SMPN di Kota Bandung, dikarenakan belum meratanya antara SDN dengan SMPN sehingga SMPN-SMPN di Kota Bandung belum bisa melayani semua keinginan masyarakat yang menginginkan anaknya diterima di SMPN. Kemudian informan ke-2 mengatakan bahwa blank spot area terjadi karena tidak meratalah tempat-tempat satuan pendidikan contoh di riung bandung tidak ada sekolah, ke SMPN 48 jauh, ke SMPN 51 jauh, ke SMPN 8 jauh dank e SMPN 54 jauh juga maka solusinya bagi pengembang apartemen suite buat satu lantai untuk sekolah di apartemen suite, blank spot terjadi karena tidak meratanya satuan pendidikan di tempat tertentu. Teori Lane (2000) mengemukakan bahwa Output merupakan hasil jangka pendek. Berdasarkan hasil observasi maka persepsi Penulis bahwa 1) kuota zonasi sudah terpenuhi tapi ternyata masih banyak peserta didik yang tidak diterima ke SMPN; 2) seharusnya banyak peserta didik yang diterima ke SMPN di Kota Bandung namun dikarenakan jumlah SMPN yang sedikit sehingga menyebabkan daya 
tampung untuk di kelas sedikit; 3) seharusnya tidak terjadi "Blank Spot Area" namun kenyataan dan fakta dilapangan terjadinya "Blank Spot Area" dikarenakan kurangnya jumlah SMPN-SMPN, khususnya SMPN di daerah perumahanperumahan atau di area padat penduduk.

9. Outcome. Menurut informan ke-6 bahwa dengan diimplementasikan kebijakan zonasi pada PPDB jenjang SMPN di Kota Bandung tahun 2018 tidak dapat meningkatkan kualitas pendidikan melainkan terjadinya penurunan kualitas pendidikan juga tidak ada pemerataan dan keadilan dalam mengakses pendidikan di Kota Bandung. Teori Mazmanian dan Sabatier mengemukakan bahwa outcome merupakan hasil dari akibat yang baru terlihat jangka panjang. Berdasarkan hasil observasi maka persepsi Penulis bahwa kualitas pendidikan baru terlihat meningkat atau tidak apabila peserta didik yang pada tahun 2018 masihk kelas 1 mengikuti UN ketika mereka kelas 3, dari hasil UN tersebut akan terlihat kualitas pendidikan meningkat atau tidak kemudian untuk pemerataan kualitas layanan pendidikan di Kota Bandung tidak akan merata apabila jumlah SMPN tidak bertambah begitu juga kualitas gurunya.

\section{SIMPULAN}

Berdasarkan hasil penelitian dan pembahasan Penulis dapat menyimpulkan bahwa suatu kebijakan publik tidak bisa dibilang sebagai kebijakan gagal maupun tidak gagal apabila tidak melalui implementasi, begitu juga kebijakan zonasi tidak bisa dibilang sebagai kebijakan gagal maupun tidak gagal apabila tidak melalui proses implementasi. Setelah melewati proses implementasi maka dapat diketahui formulasi dari kebijakan zonasi yang digunakan pada PPDB jenjang SMPN di Kota Bandung tahun 2018 salah atau benar. Kebijakan zonasi yang digunakan pada PPDB jenjang SMPN di Kota Bandung pada tahun 2018 di dalam pengimplementasiannya mengalami berbagai macam masalah, yakni dilihat dari permasalahan keragaman perilaku sasaran, keterpaduan hierarki di dalam lingkungan dan diantara lembaga-lembaga/instansi-instansi pelaksana dan dukungan publik.

Faktor keragaman perilaku sasaran.
Semakin beragam perilaku yang diatur, semakin sulit upaya untuk membuat peraturan yang tegas dan jelas. Dengan demikian semakin besar kebebasan bertindak (diskresi) yang harus diberikan kepada para pehabat di lapangan. Hal ini terjadi pada Perwal Kota Bandung Nomor 456 Tahun 2018 yang mengalami diskresi karena untuk mengakomodir keinginan dari beberapa kelompok sasaran yang tergabung di dalam FORKOMPINDA (Forum Koordinasi Pimpinan Daerah) yang pekerjaannya TNI, Guru, Kepolisian, Kejaksaan dan Kehakiman.

Faktor kedua di dasarkan pada keterpaduan hierarki di dalam lingkungan dan diantara lembaga-lembaga/instansi-instansi pelaksana. Perwal Kota Bandung Nomor 456 Tahun 2018 bukan merupakan peraturan perundangan yang baik karena tidak memiliki kemampuan untuk memadukan hierarki badan-badan pelaksana, hal ini dapat dilihat dari keluarnya Perwal Kota Bandung Nomor 456 Tahun 2018 sebelum Permendikbud Nomor 14 Tahun 2018 keluar sehingga Pemerintah Kota Bandung memakai Permendikbud tahun lalu. Hasil penelitian menunjukkan di bagian mengingat, nomor 6 di dalam Perwal Kota Bandung Nomor 456 Tahun 2018 merujuk kepada Permendikbud Nomor 17 Tahun 2017 seharusnya di bagian mengingat, nomor 6 di dalam Perwal Kota Bandung Nomor 456 Tahun 2018 merujuk kepada Permendikbud yang berlaku dan digunakan pada tahun 2018. Kementerian Pendidikan Dan Kebudayaan dan Dinas Pendidikan Kota Bandung merupakan badanbadan semi otonom sehingga seringkali mengalami kesukaran untuk mewujudkan tindakan yang terkoordinasi.

Faktor ketiga di dasarkan pada dukungan publik. Publik banyak yang tidak mendukung implementasi kebijakan zonasi pada PPDB jenjang SMPN di Kota Bandung tahun 2018 dikarenakan banyak peserta didik yang memiliki NEM dan nilai yang tinggi/bagus namun karena domisilinya jauh dari sekolah dan juga solusi yang diberikan oleh Dinas Pendidikan Kota Bandung untuk kuota prestasi hanya $5 \%$ maka mereka tidak diterima dan 
orang tua dari kelompok sasaran tidak mau menyekolahkan anaknya ke SMPN dekat dengan rumahnya karena sarana dan prasarana SMPN tersebut tidak sama dengan SMPN Favorit.

\section{DAFTAR PUSTAKA}

Akip, Haedar. (2010). "Implementasi Kebijakan: Apa, Mengapa, dan Bagaimana”

Bintoro, R.F.A. (2018). "Persepsi Masyarakat Terhadap Implementasi Kebijakan Zonasi Sekolah Dalam Penerimaan Peserta Didik Baru (PPDB) Tingkat SMA Tahun Ajaran 2017/2018 Di Kota Samarinda"

Dewi, K.E., Septiana, Ririn. (2018). "Evaluation of Zoning Student Recruitment System in Year 2018. Proceeding International Seminar On Education. Innovation Issues and Challenges in Education for Education Sustainability"

Hogwood, B.W. dan L.A. Gunn. (1984). Policy Analysis for the real Word. Oxford: Oxford University Press.

Lane, Jan-Erik. (2000). The Public Sector. Concepts, Model and Approaches. London: Sage Publication Inc.

Lester, James P. dan Joseph Stewart, JR.(2000). Public Policy: An Evolution Approach. Wadsworth.

Mazmanian, Daniel dan Paul A. Sabatier. (1983). Implementation and Public Policy. London: Scott, Foresman and Company.

Nasution. (1996). Metode Penelitian Kualitatif Naturalistik. Jakarta: Sinar Grafika.

Ndraha, Taliziduhu. (1997). Metodologi Ilmu Pemerintahan. Jakarta: Rineka Cipta.

Rusli, Budiman. (2015). Kebijakan Publik Membangun Pelayanan Publik Yang Responsif. Jawa Barat: CV ADOYA Mitra Sejahtera.

Wahab, Solichin Abdul. (1997). Analisis Kebijakan: Dari Formulasi ke Implementasi Kebijakan Negara. Malang. (2004). Analisis

Kebijaksanaan, Jakarta: PT Bumi Aksara. (2017). Analisis Kebijakan. Dari Formulasi Ke Penyusunan Model-Model Implementasi Kebijakan
Publik, Jakarta: PT Bumi Aksara.

Undang-Undang Nomor 25 Tahun 2009 Tentang Pelayanan Publik

Peraturan Menteri Pendidikan Dan Kebudayaan (Permendikbud) Nomor 14 Tahun 2018 tentang Penerimaan Peserta Diidk Baru Pada Taman Kanak-Kanak, Sekolah Dasar, Sekolah Menengah Pertama, Sekolah Menengah Atas, Sekolah Menengah Kejuruan, Atau Bentuk Lain Yang Sederajat Peraturan Pemerintah Nomor 13 Tahun 2015 tentang Standar Nasional Pendidikan

Peraturan Wali Kota Bandung (Perwal) Nomor 456 Tahun 2018 tentang tentang Tata Cara Penerimaan Peserta Didik Baru Pada Taman Kanak-Kanak/ Raudhatul Athfal, Sekolah Dasar/Madrasah Ibtidaiyah Dan Sekolah Menengah Pertama/ Madrasah Tsanawiyah

Peraturan Wali Kota Bandung (Perwal) Nomor 553 Tahun 2017 tentang Tata Cara Penerimaan Peserta Didik Baru Pada Taman KanakKanak/ Raudhatul Athfal, Sekolah Dasar/Madrasah Ibtidaiyah Dan Sekolah Menengah Pertama/ Madrasah Tsanawiyah

Pöder, Kaire, Lauri, Triin., Veski, Andre. (2016). "Does School Admission by Zoning Affect Educational Inequality? A Study of Family Background Effect in Estonia, Finland, and Sweden"

Purwanti, Dian, Irawati, Ira, Adiwisastra, Josy. (2018). "Efektivitas Kebijakan Penerimaan Peserta Didik Baru Sistem Zonasi Bagi Siswa Rawan Melanjutkan Pendidikan"

Sari, A.U.W., Imron, Ali, Sobri, A.Y. (2016). "Efektivitas Penerimaan Peserta Didik Baru (PPDB) Melalui Sistem Penerimaan Peserta Didik Online"

Surat Keputusan Kepala Dinas Pendidikan Kota Bandung Nomor 420/2513-Disdik tentang Petunjuk Teknis Penerimaan Peserta Didik Baru Pada Taman Kanak-Kanak Dan Sekolah Tahun Pelajaran 2018/2019 Di Kota Bandung

Undang - Undang RI Nomor 20 Tahun 2003 tentang Sistem Pendidikan Nasional

Wahab, Solichin Abdul. (1997). Analisis Kebijakan: Dari Formulasi ke Implementasi Kebijakan Negara. Malang. 
(2004). Analisis

Kebijaksanaan, Jakarta: PT Bumi Aksara.

(2017). Analisis

Kebijakan. Dari Formulasi Ke Penyusunan Model-Model Implementasi Kebijakan Publik, Jakarta: PT Bumi Aksara.

Warsita, Bambang. (2015). "Evaluasi Sistem Penerimaan Peserta Didik Baru (PPDB) Online Untuk Peningkatan Kualitas Pembelajaran"

Wulandari, Desi. (2018). "Pengaruh Penerimaan Peserta Didik Baru Melalui Sistem Zonasi Terhadap Prestasi Belajar Siswa” 